\title{
Effect of Fuel Combustion Products on Carbon Dioxide Uptake Dynamics of Chlorophyll Synthesizing Microalgae
}

\author{
Vasyl Volodymyrovych Dyachok ${ }^{1 *}$, Solomiya Mandryk', \\ Victiria Katysheva', Serhiy Huhlych'1 \\ 1 Lviv Polytechnic National University, S. Bandery str. 12, 79013 Lviv, Ukraine \\ * Corresponding author's e-mail: dyachokvasil@gmail.com
}

\begin{abstract}
The research on the effect of sulfur oxides $\left(\mathrm{SO}_{2}\right)$, nitrogen oxides $\left(\mathrm{N}_{\mathrm{x}} \mathrm{O}_{\mathrm{y}}\right)$ and phosphorus oxides $\left(\mathrm{P}_{2} \mathrm{O}_{5}\right)$ on carbon dioxide $\left(\mathrm{CO}_{2}\right)$ uptake dynamics of chlorophyll synthesizing microalgae was conducted. The analytic dependences of microalgae growth rates under their $\mathrm{CO}_{2}$ uptake, $\mathrm{SO}_{2}, \mathrm{~N}_{\mathrm{x}} \mathrm{O}_{\mathrm{y}}$ and $\mathrm{P}_{2} \mathrm{O}_{5}$ concentrations were obtained. Mathematical models enabling to predict the maximum values of $\mathrm{SO}_{2}, \mathrm{~N}_{\mathrm{x}} \mathrm{O}_{\mathrm{y}}$ and $\mathrm{P}_{2} \mathrm{O}_{5}$ oxides concentrations without inhibiting the $\mathrm{CO}_{2}$ uptake dynamics of chlorophyll synthesizing microalgae were built based on the obtained experimental research results.
\end{abstract}

Keywords: carbon dioxide, sulfur oxides, nitrogen oxides, phosphorus oxides, Chlorella, chlorophyll synthesizing microalgae, biomass growth

\section{INTRODUCTION}

One of the most important environmental problems of the $21^{\text {st }}$ century is general planetary climate change. In latest decades, the concentration of gases that cause the greenhouse effect in the atmosphere has been increasing due to the anthropogenic activity. This leads to destructive consequences for the planet and makes the problem of climate change essential in the field of environmental protection. There are many ways for the solution of this problem, particularly reduction of the $\mathrm{CO}_{2}$ concentration with the help of biological methods of industrial gas emissions purification using microalgae photosynthetic facilities.

The main sources of carbon dioxide in the atmospheric air are solid, liquid or gas fuel combustion products. Combustion co-products are always $\mathrm{SO}_{2}, \mathrm{~N}_{\mathrm{x}} \mathrm{O}_{\mathrm{y}}$ and $\mathrm{P}_{2} \mathrm{O}_{5}$. The presence of these gases will undoubtedly affect the $\mathrm{CO}_{2}$ uptake dynamics of chlorophyll synthesizing microalgae of Chlorella type. This is why it was important to study the effect of other mentioned greenhouse gases on this process.
Among famous methods, biological purification has consistent advantages owing to the great capacity of microorganisms to adapt to very unfavourable conditions, for example, high concentration of contaminants and their mixture and toxicity, which makes this method the most effective and the safest. Setting the boundary concentrations of toxicants in photobioreactors where the processes of greenhouse gases uptake by microalgae take place is of urgent need today.

In literature, there is very little information about the effect of sulfur oxides, nitrogen oxides and phosphorus oxides on the $\mathrm{CO}_{2}$ uptake dynamics of chlorophyll synthesizing microalgae in water medium. In works [Chiu, et al. 2011; 2014], some data concerning the effect of $\mathrm{SO}_{2}$, $\mathrm{N}_{\mathrm{x}} \mathrm{O}_{\mathrm{y}}$ on carbon dioxide uptake processes by microalgae are given. Yet, these data are of little efficiency. This is why, it is important to study the effect of the afore-mentioned oxides on vital activity of microalgae as the most important carbon dioxide absorbers.

The research was aimed at studying the effect of sulfur oxide, nitrogen oxides and phosphorus oxide on the carbon dioxide uptake dynamics by 
chlorophyll synthesizing microalgae of Chlorella type in water medium.

\section{MATERIALS AND METHODS}

The object of observation in the process of conducting experimental studies involved a culture of green microalgae - Chlorella. Standard nutrient medium containing Chlorella was inserted into water medium. The cultivation of Chlorella lasted 11 days in six photobioreactors with the volume of $1 \mathrm{dm}^{3}$. Microalgae receive nutrition compounds - carbon dioxide and elements of microalgae cell mineral nutrition directly from the surrounding liquid medium, assimilating them with their entire surface. Since microalgae assimilate $\mathrm{SO}_{2}, \mathrm{~N}_{\mathrm{x}} \mathrm{O}_{\mathrm{y}}$, and $\mathrm{P}_{2} \mathrm{O}_{5}$ oxides as $\mathrm{HSO}_{3}^{-}, \mathrm{NO}_{3}^{-}, \mathrm{H}_{2} \mathrm{PO}_{4}^{-}$anions, their effect on the chlorophyll synthesizing microalgae growth was studied under different values of their concentrations. In the first photobioreactor, the concentration of $\mathrm{HSO}_{3}^{-}$, anion was -0.001 $\mathrm{mg} / \mathrm{ml}$, in the second $-0.002 \mathrm{mg} / \mathrm{ml}$, in the third $-0.003 \mathrm{mg} / \mathrm{ml}$, in the fourth $-0.004 \mathrm{mg} / \mathrm{ml}$. For studying the effect of nitrogen oxides on chlorophyll synthesizing microalgae growth in the first photobioreactor, the concentration of $\mathrm{NO}_{3}{ }^{-}$anion was $8.5 \mathrm{mg} / \mathrm{m}^{3}$, in the second $-15.6 \mathrm{mg} / \mathrm{m}^{3}$, in the third $-34 \mathrm{mg} / \mathrm{m}^{3}$ and in the fourth -68 $\mathrm{mg} / \mathrm{m}^{3}$. In turn, for studying the effect of phosphorus oxide $\left(\mathrm{P}_{2} \mathrm{O}_{5}\right)$ on chlorophyll synthesizing microalgae growth in the first photobioreactor concentration of $\mathrm{H}_{2} \mathrm{PO}_{4}^{-}$anion was $0.02 \mathrm{mg} / \mathrm{m}^{3}$, in the second $-0.04 \mathrm{mg} / \mathrm{m}^{3}$, in the third -0.06 $\mathrm{mg} / \mathrm{m}^{3}$, in the fourth $-0.08 \mathrm{mg} / \mathrm{m}^{3}$, in the fifth $0.1 \mathrm{mg} / \mathrm{m}^{3}$ Accordingly, a control solution was placed that did not contain any appropriate anions in three research versions.

The biomass growth of chlorophyll-synthesizing microalgae was defined with the photocolorimeter method using blue light filter according to the Beer-Lambert law. Since optical light attenuation under given wavelength is proportional to the microalgae concentration, the obtained experimental data of microalgae biomass accumulation depending on time under the limits of studied sulfur oxide, nitrogen oxide and phosphorus oxide concentrations are proportional to the values of optical densities. The measurements of optical density of studied and control solutions were conducted according to the comparison solution. In our case, the comparison solution was water.

\section{RESULTS AND DISCUSSION}

The basis of cell's mass exchange with outer medium processes is a complex sequence of certain order biochemical reactions organized in time and space, as a result of which alteration of oxides, toxicants concentrations, quantity of separate cells, microalgae biomass etc. takes place.

Managing the microalgae cultivation conditions under the presence of toxicants is a necessary condition for obtaining high productivity of microalgae culture in industrial scales, which will guarantee high purification level of gas emissions.

One should assume that similarly to the $\mathrm{CO}_{2}$ fuel combustion products $\mathrm{SO}_{2}, \mathrm{~N}_{x} \mathrm{O}_{y}$ and $\mathrm{P}_{2} \mathrm{O}_{5}$ are captured by microalgae cells by analogical mechanism that can conditionally be divided into the following phases:

- transmission of oxides from gas medium into liquid (microalgae cultivation medium);

- placing oxides to microalgae surface colony;

- diffusion of oxides in microalgae colony intercellular space to microalgae cell surface;

- diffusion of oxides through microalgae cell porous shell,

- metabolism of oxides in cell volume,

With the help of both active and passive transportation, $\mathrm{CO}_{2}, \mathrm{SO}_{2}, \mathrm{~N}_{\mathrm{x}} \mathrm{O}_{\mathrm{y}}$, and $\mathrm{P}_{2} \mathrm{O}_{5}$ penetrate inside through cell membrane. Active transportation requires using an enzyme system for transporting oxides dissolved in water through microalgae cell membrane. Passive transportation is processed by penetration through pores according to the concentration gradient. The process of passive transportation leads to setting the concentrations equilibrium to both sides of chlorophyll synthesizing microalgae cell membrane. This way of transportation through membrane is typical only for hydrophilic compounds - water and low molecular ions.

Main parameter characterizing microalgae growth:

$$
\Delta \mu=\Delta C_{l} / C \times \Delta t
$$

where: $\Delta \mu-$ growth specific velocity or specific growth rate $\left(\right.$ day $\left.^{-1}\right)$,

$C$ - microalgae concentration,

$t$ - time.

On the other hand, growth rate $\mu$ can be measured from the following equation:

$$
\Delta C / \Delta t=\mu \times C
$$


According to the equation, growth rate $\mu$ characterizes the relative growth of microalgae in time unit. Studies should be conducted in exponential growth period, i.e. in the time duration that is called exponential growth phase [Dyachok 2010]. Then, after integrating equation (2), we measure permanent integration under condition that in initial time moment $t=0$ there is output concentration of microalgae cells $C_{0}$ :

$$
C=C_{0} \times \exp (\mu t)
$$

Since logarithmic dependence of microalgae cell concentration on time in the exponential growth period is a linear dependence - it enables to measure growth rate $\mu$ as tangent angle of the straight line. That is why by inserting experimental data into the equation (3) we receive the dependence $\operatorname{Ln} C=\mathrm{f}(t)$ that is shown in (Fig. 3, 6, 8).

In microalgae inner cell medium, complex process of biochemical transformations takes place. In clear sequence with high velocity numerous, biochemical reactions take place. Reactions velocity and their sequence are measured by presence of specific ferments - catalyzers.

The action mechanism of enzymes consists in that together with substance-substrate they create specific enzyme-substrate complex. Addition of the substrate to enzyme takes place in catalytic center zone that facilitates the biochemical reaction process. Resulting from biochemical evolution, the catalytic center obtains such structure and special configuration that enables to interact with only certain substance-substrate [Hubskyy and Yu 2007, Zolotaryova, et al. 2008].

The substances that are able to inhibit enzyme reactions are called inhibitors. During studies on the effect of inhibitors on enzyme reactions, information was obtained concerning substance specificity of enzymes, nature of functioning groups that compound active enzyme center, mechanism of enzyme activity and participation of certain functioning groups in supporting specific conformation of enzyme molecule. Inhibition of different enzymes by specific cellular components is one of the factors that manage the process of enzyme reactions in the cell. Such cellular component in this case, based on experimental research results happens to be sulfur dioxide that performs the role of inhibitor by penetrating through cellular membrane into microalgae cell`s inner medium.

The inhibitors that reduce the activity of enzymes under condition of interaction with the same active centers functioning groups as substrates are called competitive. In contrast, the inhibitors that reduce the activity of enzymes under condition of interaction with other functioning groups are called noncompetitive. Competitive inhibition can be weakened or completely removed by increasing the substrate concentration, in our case - carbon dioxide. The substrate concentration does not affect noncompetitive inhibition.

Competitive inhibition is easier to discover by building Lineweaver-Burk plots, i.e. graphics in coordinates $1 / v$ from $1 /[\mathrm{S}]$ under different inhibitor concentrations. Under actual competitive inhibition, it is straight lines that differ in tangent angle of inclination and cross axis of ordinate at one point (Fig. 1a).

The presence of competitive inhibitor does not change the maximum value of reaction velocity $\mathrm{V}_{\max }$. In the presence of competitive inhibitor imaginary constant value Michaelis $\mathrm{K}_{\mathrm{m}}$ is greater than its value significance that equals difference in length of segments that cut off on abscissa.

By Lineweaver-Burk plot, built for minimum three different inhibitor concentrations, one can conclude that noncompetitive inhibitor reduces the value $V_{\max }$, when the value $K_{m}$ remains constant (Fig. 1b). For competitive inhibition in set a)

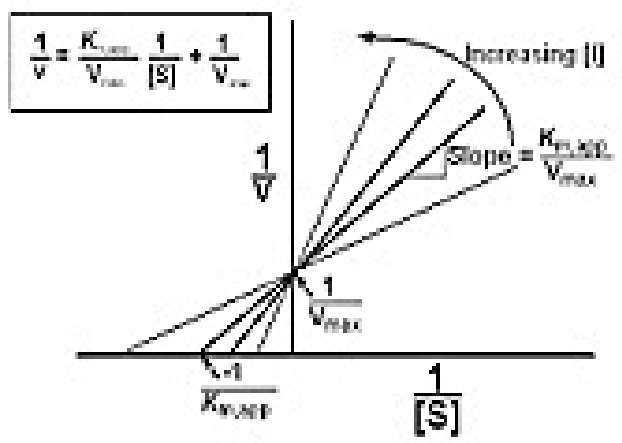

b)

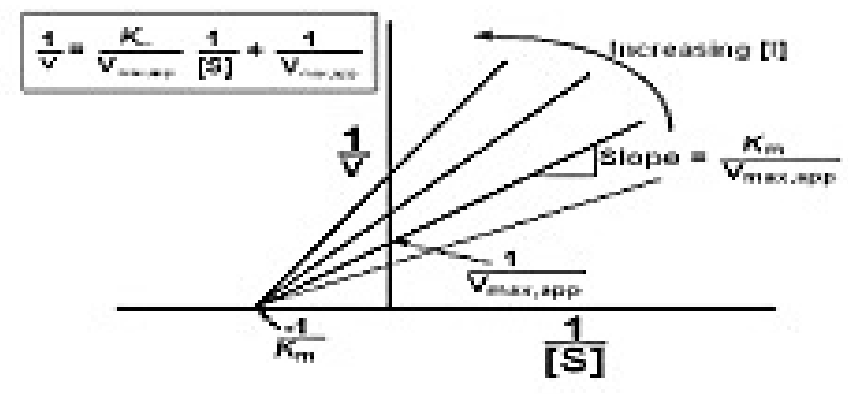

Figure 1. Lineweaver-Burk plot for, a) competitive and, b) noncompetitive inhibition by literature data [3] 
of experiments under different values of inhibitor concentrations a number of straight lines will (Fig. 1a) cross at one point on the axis of the ordinate and cut the $1 / v_{\max }$ segment off.

The velocity of biochemical processes in the cell depends not only on carbon dioxide $\left(\mathrm{CO}_{2}\right)$ and enzyme concentration but on the presence of other substances that are called inhibitors and activators. In living cell, inhibition or enzyme activation and their systems are important factors for regulation of carbon dioxide uptake dynamics under cultivation conditions.

During the processing of experimental data, the graphic dependences that illustrate alteration of microalgae concentration in time under different values of sulfur dioxide in solution under its one-time insertion were obtained (Fig. 2). Sulfur dioxide in water medium for microalgae cultivation exists as ion $\left(\mathrm{HSO}_{3}^{-2}\right)$. The obtained data show that $\left(\mathrm{HSO}_{3}^{-}\right)$considerably affects the biomass growth of microalgae cells in comparison to the control. In controlled sample, instead, its stable increase is observed. That is why it is reasonable to reckon that sulfur dioxide under conditions of experiment acts in a role of carbon dioxide (photosynthesis) uptake process inhibitor.

More detailed analysis of data in Figure 2 enables to claim that alteration of microalgae cells number in one time unit under the conditions of experiment is defined by the number of born and dead cells. Quantitatively, this process can be described by famous equation (3) that in coordinates $\ln \frac{\mathrm{C}}{\mathrm{C}_{\mathrm{o}}}=f(\mathrm{t})$, enables to define growth rate $\mu$ [Dyachok et al. 2017].

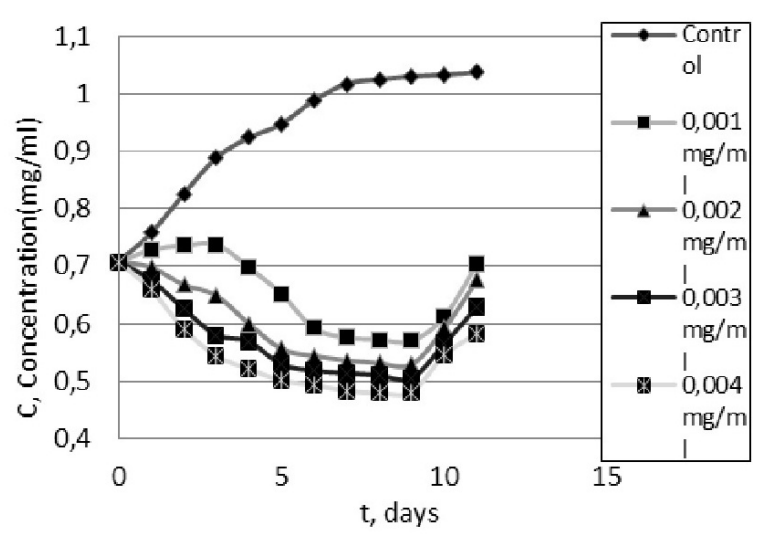

Figure 2. Alteration of microalgae cells concentration in time under appropriate values of inhibitor concentrations
Growth rate can be $\mu>0$ under condition of action of certain inhibitor photosynthesis concentration value; it can be of negative value $\mu<0$ and can also equal zero.

Experimental research data (Fig. 1, 2) in coordinates $\ln \frac{\mathrm{C}}{\mathrm{C}_{\mathrm{o}}}=f(\mathrm{t})$, are graphically shown in Figure 3.

Under the concentrations values $\mathrm{HSO}_{3}^{-2}$ : $0.001 \mathrm{mg} / \mathrm{ml} ; 0.002 \mathrm{mg} / \mathrm{ml} ; 0.003 \mathrm{mg} / \mathrm{ml} ; 0.004$ $\mathrm{mg} / \mathrm{ml}$, the growth rates are below zero $\mu<0$. The quantitative values of rates are relatively the following: $\mu_{4}=-0.0563$ day $^{-1} ; \mu_{5}=-0.0543$ day $^{-1} ; \mu_{6}$ $=-0.0537$ day $^{-1} ; \mu_{7}=-0.0406$ day $^{-1}$. This way inhibition characteristics of sulfur dioxide by given concentration values are obvious.

The two inhibition alternatives that are called competitive and noncompetitive are of considerable theoretical and practical interest. Full competitive inhibition takes place when inhibitor prevents the production of enzyme-substrate complex, i.e. attainment of enzyme active center by substrate becomes impossible.

At the present phase of research, it was important to set competitive or noncompetitive inhibition of the process. In order to do so, having processed the experimental data according to the presented theoretical basis, we have obtained Lineweaver-Burk plot in coordinates $1 / V$ from $1 / S$ (Fig. 4).

Comparing the literature data LineweaverBurk plot (Fig. lb) to built graphical dependence (Fig. 4) by experimental data (Fig. 2), their similarity can be claimed. That is why we believe that the obtained results confirm noncompetitive inhibition, the case when inhibitor joins enzyme

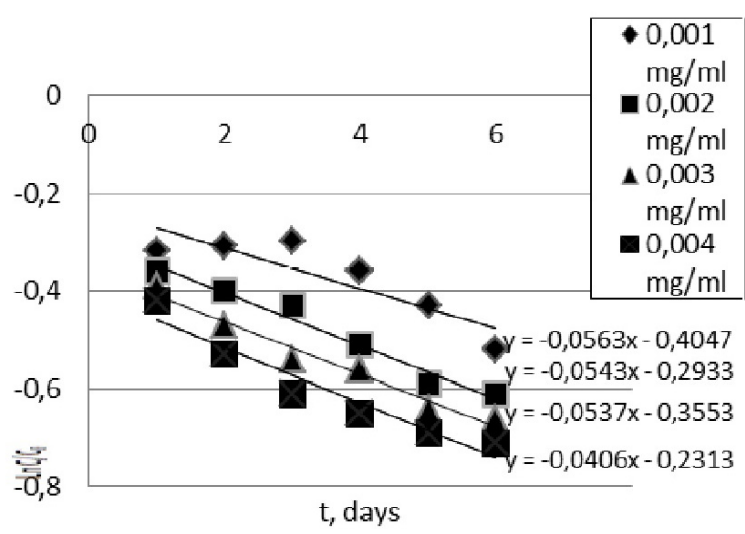

Figure 3. Dependence of microalgae cell concentration logarithm alteration on time under appropriate $\mathrm{HSO}_{3}$ - concentrations 


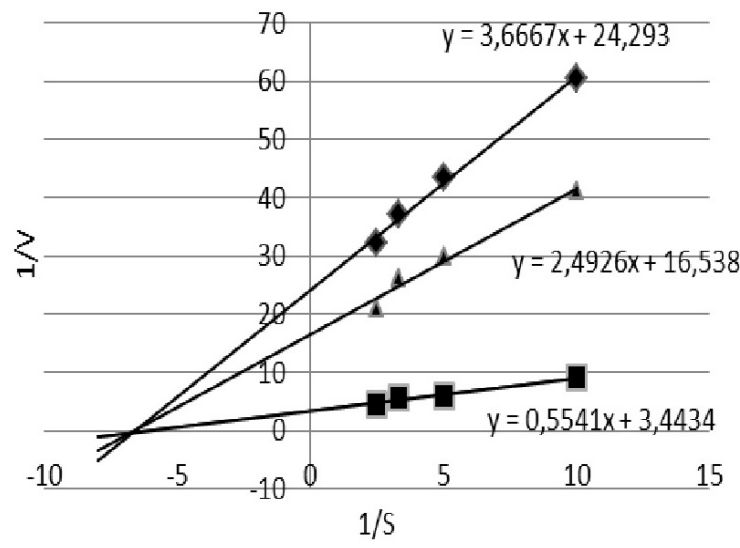

Figure 4. Lineweaver-Burk plot for defining $\mathrm{SO}_{2}$ inhibition type in the studied object

not in the active center where substrate ties, but in another place of molecule. That is, noncompetitive inhibitor reduces enzymes activity, without touching its active center, without preventing the production of enzyme-substrate complex, it ties with enzyme-substrate complex, creating inactive complexes.

Typical for obtained graphic (Fig. 4) is $\epsilon$ alteration $1 / V_{\max }$ when $K_{M}$ constant remains without changes, this means that under any concentration inhibitor experimental curves in coordinates Lineweaver-Burk create lines that cross at point $1 / K_{M}$ cutting off $1 / V_{\max }$ segments, which enables to define the $K_{M}$ value and $1 / V_{\max }$ under inhibitor concentration $-0.001 \mathrm{mg} / \mathrm{ml}, K_{M}=6.2 \mathrm{mg} /$ $\mathrm{ml}$, and $1 / V_{\max }=24.29 \mathrm{mg} / \mathrm{ml} \cdot$ day, under concentration $-0.002 \mathrm{mg} / \mathrm{ml}, K_{M}=6.2 \mathrm{mg} / \mathrm{ml}, 1 / V_{\max }=$ $16.54 \mathrm{mg} / \mathrm{ml} \cdot$ day, for $0.004 \mathrm{mg} / \mathrm{ml}, K_{M}=6.2 \mathrm{mg} /$ $\mathrm{ml}$, and $1 / V_{\max }=3.44 \mathrm{mg} / \mathrm{ml} \cdot$ day.

Further, we studied the effect of nitrogen oxides and phosphorus on the microalgae biomass growth. On the basis of the experimental data results and calculated values, we obtained graphical dependences of microalgae cells concentration alteration on time, under appropriate nitrogen oxides concentrations $\left(\mathrm{N}_{\mathrm{x}} \mathrm{O}_{\mathrm{y}}\right)$ and phosphorus oxide concentrations $\left(\mathrm{P}_{2} \mathrm{O}_{5}\right)$ in solution under their one-time insertion in illustrations 5 and 7. While analyzing data (Fig. 5, 7 ) it is worth mentioning that microalgae cell biomass growth within time considerably depends on the nitrogen oxides concentrations $\left(\mathrm{N}_{\mathrm{x}} \mathrm{O}_{\mathrm{y}}\right)$ and phosphorus oxide concentrations $\left(\mathrm{P}_{2} \mathrm{O}_{5}\right)$ in comparison to the control where $\mathrm{NO}_{3}^{-}$ and $\mathrm{H}_{2} \mathrm{PO}_{4}^{-}$anions are absent. That is why they can be referred to as activators of photosynthesis process.
With increase of nitrogen oxides concentrations $\left(\mathrm{N}_{\mathrm{x}} \mathrm{O}_{\mathrm{y}}\right)$ and phosphorus oxides concentrations $\left(\mathrm{P}_{2} \mathrm{O}_{5}\right)$ the growth of microalgae cells is increased in comparison to the control. Such superiority of microalgae concentrations values is only to certain oxides concentration value. As it is seen in (Fig. 5), 4 sample on second day behaves similarly to others, i.e. adaptation phase to two days takes place, from third day a slight growth begins that on the $5^{\text {th }}$ day is higher than in the controlled sample, yet from sixth sample decrease is observed and in the next five days, reduction of growth takes place. Under higher values of concentrations $\left(\mathrm{N}_{\mathrm{x}} \mathrm{O}_{\mathrm{y}}\right)$ microalgae death takes place in comparison to the control.

Growth rates values $\mu$ we measured analogically, using this methodology, they were accordingly: 0.075 day $^{-1} ; 0.076$ day $^{-1} ; 0.078$ day $^{-1}$ (Fig. 6).

Concerning phosphorus oxides, similar situation is observed, only under other $\mathrm{H}_{2} \mathrm{PO}_{4}^{-}$anion

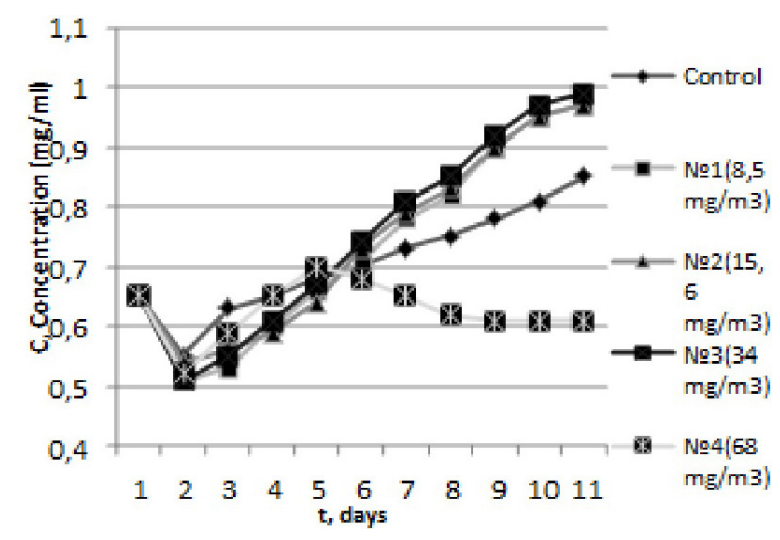

Figure 5. Dependence of microalgae cell concentration in time under appropriate $\mathrm{NO}_{3}^{-}$concentrations

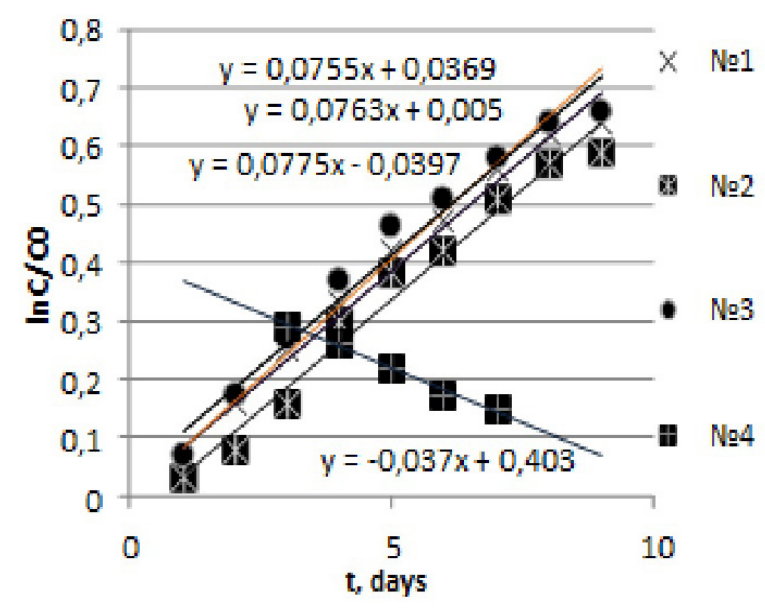

Figure 6. Dependence of microalgae cell suspension concentration logarithm on time (under appropriate $\mathrm{NO}_{3}^{-}$concentrations) 
concentrations. In fifth sample (Fig. 7), where the concentration is $0.1 \mathrm{mg} / \mathrm{m}^{3}$, negative microalgae biomass growth is observed. This means that harmful dosage of phosphorus oxide $\left(\mathrm{P}_{2} \mathrm{O}_{5}\right)$ for microalgae growth takes place. At the same time, under lower values of phosphorus oxide $\left(\mathrm{P}_{2} \mathrm{O}_{5}\right)$ concentrations, only the increase of microalgae cell biomass is observed in comparison to the control. The main parameter, i.e. growth rate value $\mu$ was measured in Figure 8 .

Mathematical model of microalgae biomass growth depending on activators (oxides) concentration is illustrated.

Mathematical formula of microalgae biomass growth under nitrogen oxides concentration growth model is illustrated;

$$
\left\{\begin{array}{l}
\frac{d C}{d x}=\mu_{1} C-\mu_{2} C \\
\frac{d C}{d \mathrm{x}}=\mu_{1} C \\
x=0, C=C_{o}
\end{array}\right.
$$

where: $x$ - nitrogen oxides concentration;

$\mu_{1}, \mu_{2}-$ growth rates under favourable (activation) and unfavourable (inhibition) values of nitrogen oxides concentration; $C-$ microalgae concentration in cultivation medium.

Its equation has several analytic formulas, one of which enables to calculate the critical values of oxides $\mathrm{N}_{x} \mathrm{O}_{\mathrm{y}}$, and $\mathrm{P}_{2} \mathrm{O}_{5}$ concentrations under known values of growth rates $\mu$;

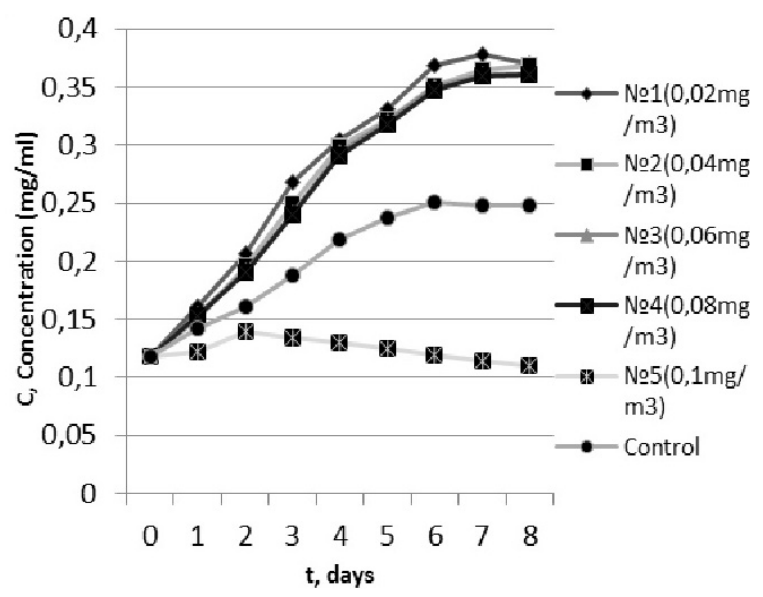

Figure 7. Dependence of microalgae cell concentration alteration in time under appropriate $\mathrm{H}_{2} \mathrm{PO}_{4}^{-}$concentrations

$$
x_{\max }=\frac{\mathbf{h} \mu_{2}-\mathrm{h} \mu_{1}}{\left(\mu_{1}+\mu_{2}\right)}
$$

Appropriate values of growth rates $\mu_{1}, \mu_{2}$ were calculated using mathematical processing data on microalgae biomass growth experimental studying results. After inserting the obtained values into equation (7) we calculated the nitrogen oxides concentration optimum value in cultivation medium. It is the nitrogen oxides concentration under which maximum value of microalgae biomass concentration is obtained in cultivation medium. For verification of the mathematical model adequacy and its conducted calculation, we build graphic of microalgae concentration growth dependence on the $\mathrm{N}_{\mathrm{x}} \mathrm{O}_{\mathrm{y}}$ concentration based on the experimental data. Additionally, we built analogical graphics of $\mathrm{P}_{2} \mathrm{O}_{5}$ concentration dependence on growth rate $\mu$ and microalgae concentration growth.

Figure 10 indicates that maximum microalgae concentration growth is obtained under the concentration $\mathrm{N}_{\mathrm{x}} \mathrm{O}_{\mathrm{y}} \approx 18 \mathrm{mg} / \mathrm{m}^{3}$. This means that the mathematical model is rather accurate in describing process of the experiment, and the obtained results enable to forecast equipment for conducting greenhouse gases technology under the conditions of $\mathrm{N}_{\mathrm{x}} \mathrm{O}_{\mathrm{y}}$ presence. The adequacy of mathematical model was proven on example of nitrogen oxide concentration values $\mathrm{N}_{\mathrm{x}} \mathrm{O}_{\mathrm{y}}$ in Figure 10. Additionally, we built analogical graphics of $\mathrm{P}_{2} \mathrm{O}_{5}$ concentration dependence on growth rate $\mu$ and microalgae concentration growth (Fig. 9).

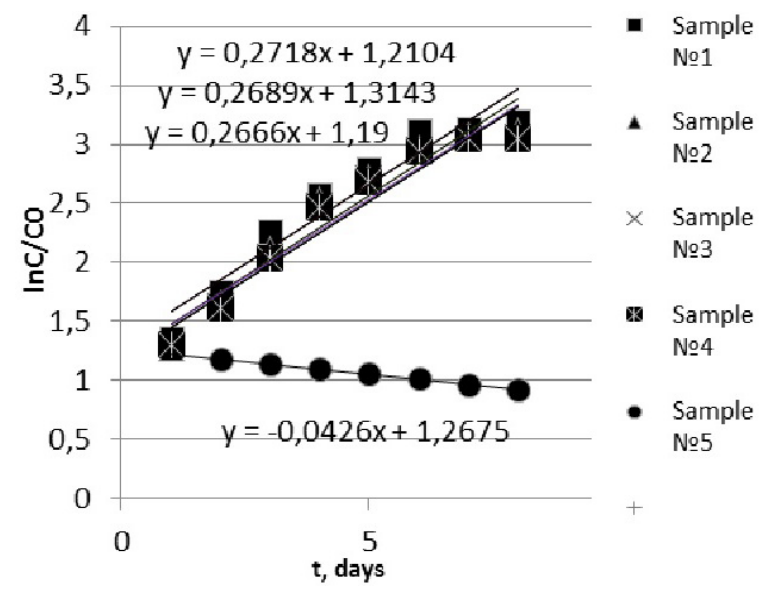

Figure 8. Dependence of microalgae cell suspension logarithm alteration on time (under appropriate $\mathrm{H}_{2} \mathrm{PO}_{4}^{-}$concentrations) 


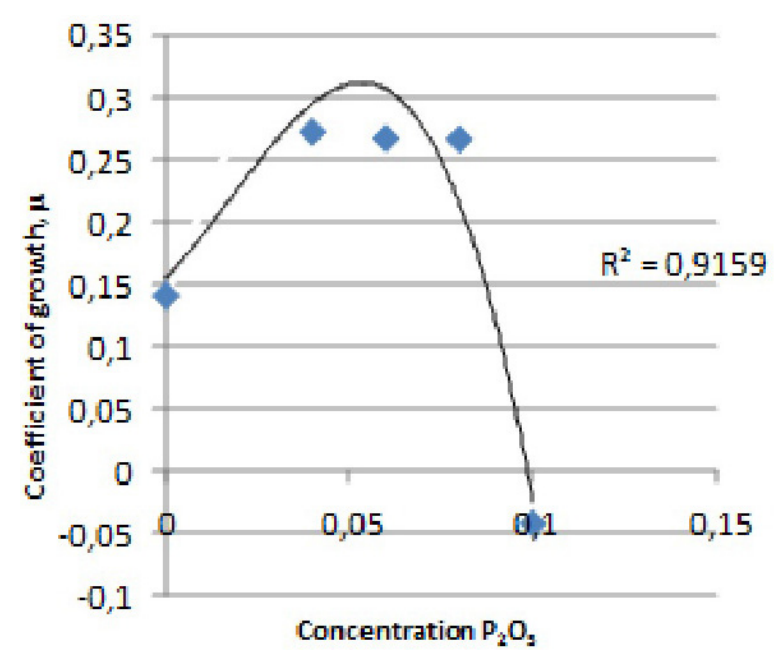

Figure 9. Microalgae growth rate $\mu$ dependence on $\mathrm{P}_{2} \mathrm{O}_{5}$ concentration

\section{CONCLUSIONS}

1. The effect of fuel combustion products (sulfur dioxide $\left(\mathrm{SO}_{2}\right)$, nitrogen dioxides $\left(\mathrm{N}_{\mathrm{x}} \mathrm{O}_{\mathrm{y}}\right)$ and phosphorus oxide $\left(\mathrm{P}_{2} \mathrm{O}_{5}\right)$ on carbon dioxide $\left(\mathrm{CO}_{2}\right)$ uptake velocity by chlorophyll synthesizing microalgae in water medium was studied.

2. The presence of noncompetitive inhibition by sulfur dioxide process of photosynthesis by chlorophyll synthesizing microalgae was set based on Lineweaver-Burk theory.

3. A mathematical model of microalgae biomass growth depending on nitrogen oxides $\left(\mathrm{N}_{\mathrm{x}} \mathrm{O}_{\mathrm{y}}\right)$ and phosphorus oxides $\left(\mathrm{P}_{2} \mathrm{O}_{5}\right)$ concentrations was built. Its equation enables the calculation of $\mathrm{N}_{\mathrm{x}} \mathrm{O}_{\mathrm{y}}$ and $\mathrm{P}_{2} \mathrm{O}_{5}$ oxides concentrations critical values under known values of growth rates $\mu$.

\section{REFERENCES}

1. Dyachok V.V., Huhlych S.I., Levko O.B. 2015. Vyvchennya vplyvu temperatury na kinetyku pohlynannya vuhlekysloho hazu mikrovodorostyamy. Visnyk Natsionalnoho Universytetu "Lvivska

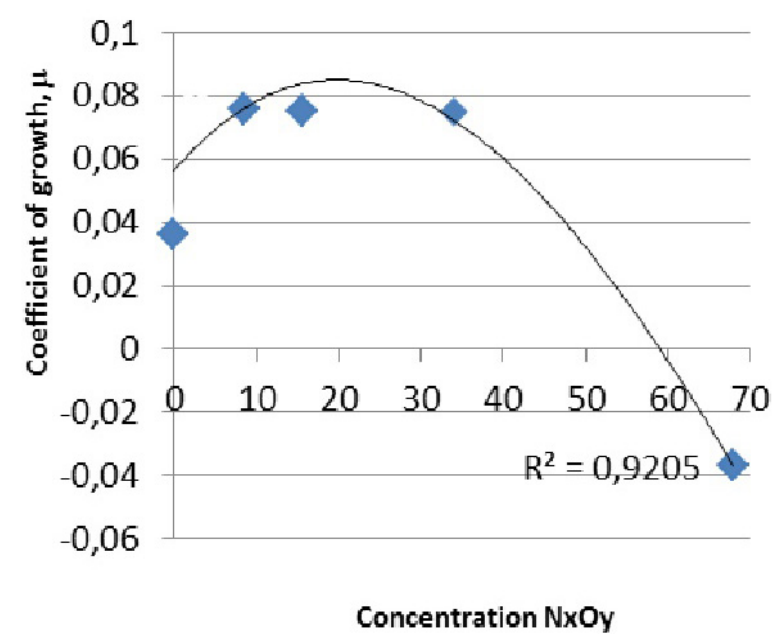

Figure 10. Microalgae growth rate $\mu$ dependence on $\mathrm{NxOy}$ concentration

politekhnika”. Khimiya, Tekhnolohiya Rechovyn ta Ikh Zastosuvannya, 812, 365-372.

2. Statsenko O.V., Vynohradova R.P. 1992. Bioorhanichna khimiya. Vyshcha shkola, pp. 278.

3. Hubskyy Yu. I. 2007. Biolohichna khimiya. Nova knyha, pp. 137.

4. Zolotaryova O.K., Shnyukova Ye.I., Syvash O.O., Mykhaylenko N.F. 2008. Perspektyv vykorystannya mikrovodorostey u biotekhnolohii. O.K. Zolotaryovoi (Ed.), Altpres, pp. 234.

5. Dyachok V. 2010. Extraction process of intracellular substance. Chemistry \& Chemical Technology. 4(2), 163-167.

6. Dyachok V., Huhlych S. 2015. Mathematical design of biological processes of complicated mass transfer. Sciences and Education a New Dimension. Natural and Technical Sciences, 41, III(5), 91-94.

7. Chiu S., Kao C., et al. 2011. Microalgal biomass production and on-site bioremediation of carbon dioxide, nitrogen oxide and sulfur dioxide from flue gas using Chlorella sp. culture. Bioresource Technology, 102, 9135-9142.

8. Chiu S., Kao C., et al. 2014. Utilization of carbon dioxide in industrial flue gases for the cultivation of microalga Chlorella. Bioresource Technology, 166, 485-493. 